\title{
The Effect of Ownership and Competitive Pressure on Firm Performance in Transition Countries: Micro Evidence from Bulgaria, Romania and Poland
}

By: Manuela Angelucci, Saul Estrin, Jozef Konings, and Zbigniew Zolkiewski

William Davidson Working Paper Number 434

January 2002 
The Effect of Ownership and Competitive Pressure on Firm Performance in Transition Countries:

\title{
Micro Evidence from Bulgaria, Romania and Poland
}

By Manuela Angelucci****, Saul Estrin*, Jozef Konings**, Zbigniew Zolkiewski***

\author{
*London Business School, London, UK \\ ** LICOS, Katholieke Universiteit Leuven, Belgium \\ *** Research Centre for Economic and Statistical Studies \\ ***** University College London, UK \\ Correspondence: \\ Jozef Konings \\ LICOS, KUL \\ Debériotstraat 34 \\ 3000 Leuven \\ Belgium \\ Email:jozef.konings@econ.kuleuven.ac.be
}

Acknowledgements:

We acknowledge financial support of a Phare Ace project on competition and firm performance. We thank Giulia Faggio and Frederic Warzynski for research assistance. We thank Rumen Dubrinski and Ion Anton for providing sector level data in Bulgaria and Romania respectively. This paper benefited from presentations at LICOS, K.U.Leuven; a Phare Ace workshop on Competition Policy in Romania and the CEPR/WDI annual conference of transition economics in Portoroz, June 2001. 


\begin{abstract}
This paper uses a unique representative firm level data set to analyse the effect of domestic and international competitive pressure and ownership changes in three emerging economies, Bulgaria Poland and Romania. Our main findings can be summarized as follows: Domestic competitive pressure, measured by market structure, and increased import penetration are associated with higher firm performance in Poland irrespective of the ownership structure of firms. Furthermore the positive effects of increased import competition are reinforced for foreign owned firms. In contrast, in Bulgaria and Romania, increased import penetration is associated with lower firm performance, while there is some evidence that more competitive market structures are associated with higher total factor productivity. However, these effects depend on the ownership structure of firms, which suggests the existence of complementarities between competitive pressure and ownership changes.
\end{abstract}

The results also indicate that privatisation has positive effects on firm performance. In particular, domestic private firms and foreign owned firms outperform state owned firms. Furthermore, there is evidence that foreign owned firms do better than domestically owned private firms especially in Bulgaria and Poland. The results on ownership are somewhat weaker for Romania.

Key words: competitive pressure, privatisation, firm performance JEL classification: D24, D40, D42, J42, L10, L33, P23, P31 


\section{Non-Technical Summary}

This paper is concerned with the analysis of firm performance, measured as total factor productivity, in three reforming economies: Bulgaria, Romania, and Poland. Poland has implemented most of the market-oriented reforms and can be considered in a further stage of economic transition than Bulgaria and Romania that are lagging behind in the transition process.

We used a large representative panel of firms in manufacturing with detailed information on output and input factors and firm ownership (company accounts data) as well as on industry variables regarding concentration and import penetration for the period 199498. We estimated an augmented production function where the log of production is a function of the log of employment, and the log of capital, and of ownership, concentration, and import penetration. Using ownership information for two consecutive years (1997 and 1998) we tested whether private foreign owned firms outperform private domestic firms and whether these outperform state owned enterprises. Using measures of market concentration and import penetration we tested whether increasing competition, measured by decreasing concentration and increasing import penetration improve firm performance. We also tested whether competitive pressure had different effects according to ownership categories so as to analyse the complementarity of reforms in transition countries. We take into account unobserved firm heterogeneity that may have an important impact on performance.

The main results of the paper can be summarized as follows:

a Competitive pressure measured by market structure was found to be associated with higher productivity performance in Poland, in Bulgaria and in Romania.

- Increased import penetration was positively associated with firm performance in Poland, but it had a negative relationship with firm performance in Bulgaria and Romania. The 
latter may be related to the existing unfavourable terms of trade, the high dependence on imports and the collapse in trade in more traditional trade sectors and the slow pace of economic improvement and firm restructuring. It may well be the case that the efficiency or technology gap that exists between importing firms and domestic ones is large. In this case domestic firms may be discouraged to restructure, which may lead to a further collapse.

口 It is found that competitive pressure has stronger effects in private firms or to put it differently privatisation is associated with higher firm performance in more competitive sectors.

口 Privatisation is in general associated with better firm performance. Private domestic firms outperform state firms in Bulgaria and in Romania. Foreign firms outperform state firms and private domestic firms in Bulgaria, but not in Romania. For Poland, both private domestic and foreign firms outperform state firms.

a The results suggest that there are complementarities between competitive pressure and ownership. They may be related to the early restructuring of Polish industries as compared to the restructuring of Romanian and Bulgarian firms so that fewer sectors in Poland are as highly concentrated as sectors in Romania and Bulgaria. 


\section{William Davidson Institute Working Paper 434}

\section{Introduction}

Two key features characterize the transition process in Central and Eastern Europe. First, transition implied the creation of a large private sector, achieved by implementing mass privatisation programmes. Second, price and trade liberalisation implied an increase in competitive pressure faced by most incumbent firms. In this paper we use a representative firm level data set to analyse how these increased competition and ownership changes have had an impact on firm performance in Bulgaria, Romania and Poland.

We make at least four main contributions. First, previous studies mostly had to rely on small samples of firms - usually of a few hundreds - collected through surveys. In contrast, this paper uses a large representative panel of firms in manufacturing with detailed information on output and input factors covering the years 1997-98 for Bulgaria and Romania, the years 1994 and 1998 for Poland. We have data on more than 1500 firms in Bulgaria, 2047 firms in Romania and 17570 in Poland. The sample contains virtually the entire population of medium and large firms in manufacturing in the above countries $\$$

Second, the data contains detailed information on ownership structure for two consecutive years, 1997 and 1998 in Bulgaria and Romania, 1994 and 1998 in Poland. We are able to measure the fraction of shares in firms held by the state and by private investors, observe its evolution over time and are able to distinguish explicitly between private domestic investors and foreign investors. This is important because it allows us to test the hypothesis that foreign firms perform better than domestic private firms, due to their potentially higher technological expertise and/or their corporate governance structure ${ }^{2}$. This distinction has not been made so far in the literature that deals with privatisation.

\footnotetext{
${ }^{1}$ For Poland the sample also includes small firms.

${ }^{2}$ It is well documented that due to the mass privatisation programmes in transition economies, many of the firms were privatised to insiders, which made restructuring of these firms more difficult. Outside ownership, such as foreign ownership, would make restructuring easier (for an overview Estrin, 2001)
} 
Furthermore, because we have data for two years we are able to control for firm specific heterogeneity, which may capture various unobservables, such as the quality of capital and labour. Since such unobserved fixed effects are likely to be positively correlated with private ownership, we are implicitly controlling for one of the potential sources of endogeneity of ownership. Frydman et al (1999) control for unobserved fixed effects in a similar way, though, they had to rely on survey data and they only included fixed effects corresponding to various groups of firms. We control for firm heterogeneity for each individual firm, even within the separate ownership groups. By analysing also the effects of corporate governance on firm performance, in combination with competitive pressure, we aim to make a contribution to the debate about the effects of privatisation on firm performance in transition countries. As surveyed by Nellis (1999) or Estrin (2001) in a number of institutionally weak transition countries, such as Russia, ownership change has so far not delivered on its promise. In this paper we analyse the effects of ownership changes on firm performance in Bulgaria and Romania, two countries that are lagging behind in the transition process and where institutions are weaker than in other countries. We then compare them to Poland, which is a step ahead in the transition process. Real GDP in Poland has been growing at an annual average rate of more than $4 \%$ since 1992, in contrast in Bulgaria and Romania, GDP growth was still negative in 1997 and 98 and they are still far below the pre-transition level of GDP (EBRD, 2000).

Third, we analyse the impact of competitive pressure on firm performance. Competitive pressure is measured at the three-digit level of sectoral disaggregation. Earlier studies had to rely on more aggregate measures of competition (e.g. Earle and Estrin, 1996) or on qualitative measures of competitive pressure (e.g. Konings, 1997). Moreover, we are able to test whether competitive pressure has different effects according to the ownership type of the firm. Thus our results can be relevant for the theoretical models that deal with the 
complementarity of reforms in transition countries (e.g. Dewatripont and Roland, 1992; Roland, 2000).

A fourth contribution of this paper lies in its comparative strength. Bulgaria and Romania are lagging behind in the transition process, as mass privatisation only started a few years ago. Poland, instead, is more advanced in terms of privatisation, governance and restructuring and development of institutions, scoring the second highest mark in the EBRD assessment of the state of the transition (EBRD, 1998 and 2000). The trade share in GDP of Bulgaria is $71.5 \%, 46.3 \%$ for Romania and $47.0 \%$ for Poland (EBRD, 1998). Recently, the flows of foreign direct investment have started to increase rapidly. By 1998 there was almost 10 fold increase in FDI in Bulgaria compared to 1991, for Romania and Poland there was even a 50 and 60 fold increase in FDI by 1998 (EBRD, 2000). This increase in FDI is a first indication that competitive pressure for domestic firms has likely gone up. It is often argued that foreign firms possess more technological know-how and expertise which makes them more efficient compared to domestic firms (e.g. Djankov and Hoekman, 1998). This may be of particular relevance for firms in transition countries, given their obsolete capital structure endemic to the communist legacy (Lizal and Svejnar, 2001).

Figures 1, 2 and 3 show the evolution of the Herfindahl index of concentration ${ }^{3}$ and import penetration in these countries during the 90s. It is clear that product market concentration is declining relatively fast and import penetration is going up, which confirms that increased competition is taking place ${ }^{4}$. While many factors point towards increased product market competition in most of the transition economies, there exists little evidence about its effects on firm performance and the existing evidence is not conclusive ${ }^{\text {t }}$. Hersch,

\footnotetext{
${ }^{3}$ For Romania, we report also the $\mathrm{C} 5$ index of concentration because the Herfindahl index is not available for the earlier years.

${ }^{4}$ Fingleton et al (1996) documents and discusses the evolution of product market concentration in transition economies and the emergence of competition policy in CEE.

${ }^{5}$ The evidence of competitive pressure on firm performance in capitalist societies is also mixed. Nickell (1996) finds positive effects for UK firms, while Blanchflower and Machin (1996) find no or weak effects.
} 


\section{William Davidson Institute Working Paper 434}

Kemme and Bhandari (1993) estimate a standard model of the determinants of price-cost margins on firm level survey data for Hungary, Poland and the former Czech and Slovak Republic. When country data are pooled they find evidence that the number of rival firms has some restraining effect on the price-cost margins of private firms. However, when countries are considered individually, there seems to exist a strong effect of rivals on price-cost margins only for Poland. Earle and Estrin (1996) investigate whether competitive forces and privatisation had an efficiency enhancing role in Russia and found that privatisation is having an impact on enterprise efficiency, but domestic market structure mostly had little effect. Brown and Earle (2000a) use Russian firm level panel data and find positive effects from domestic competition on total factor productivity, although this effect appears only gradually. They also find that imports and better transportation infrastructures generate positive effects. Carlin et al. (2001) use survey data of 3,300 firms in 25 transition countries to examine the effects of competitive pressure on restructuring and firm growth and find an important and non-monotonic effect on firm performance. They point out that the effects may vary depending on the ownership type of the firm and the presence of soft budget constraints. The mere presence of increased competitive pressure is indeed not sufficient to guarantee improved firm performance as suggested by the theoretical literature which stresses the sequencing and complementarity of reforms in transition countries (e.g. Dewatripont and Roland, 1992; Roland, 2000). For instance, if firms remain state owned the incentive inducing effects of increased competition may be weaker. Brown and Earle (2000b) develop a simple oligopoly model to show that privatising a firm is a substitute for exposing it to competitive markets, while privatising its competitors is complementary. They use Russian firm level data to report evidence, which is consistent with their model. Also Grosfeld and Tressel (2001) use data of Polish quoted firms to investigate the issue of complementarity. They find that competitive pressure and governance are complements, rather than substitutes. 


\section{William Davidson Institute Working Paper 434}

In the following section we describe the data and the econometric approach for estimating firm performance in terms of total factor productivity. Section III discusses the results and section IV is a concluding one. Our results can be summarized as follows: Competitive pressure, measured by market structure and increased import penetration, is associated with higher firm performance in Poland. In contrast, in Bulgaria and Romania, increased import penetration is associated with lower firm performance, while there is some evidence that more competitive market structures are associated with higher total factor productivity. However, these effects depend on the ownership structure of firms, which suggests the existence of complementarities between competitive pressure and ownership changes. The results also indicate that privatisation has positive effects on firm performance, especially in Bulgaria and Poland.

\section{Data and Econometric Approach}

The data that we use are based on the reported company accounts of all incorporated firms in the manufacturing sector. The data for Bulgaria and Romania cover the years 1997-98, while for Poland we have information of the same set of firms for the years 1994 and 1998. For Bulgaria and Romania the data are constrained to the larger firms. In particular, the data that we obtained satisfied at least two of the following criteria: number of employees greater than 100 , total assets and sales exceed 8 and 16 million USD, respectively. All the variables are taken from published annual company accounts, which were made consistent across countries by "Bureau Van Dyck". The data set is called the Amadeus data set. The data appendix describes the various sources and definitions of the data set and the way in which 


\section{William Davidson Institute Working Paper 434}

we retrieved ownership information from this commercial database. We can use information on 1500 firms in Bulgaria and 2047 firms in Romania. For Poland we do not face this restriction on the data, so we have also access to the small firms, which resulted in a much larger number of firms, 17570, that we could use in the analysis. The data also refer to the annual accounts and are obtained from the Polish Statistical Office. In constrast to the Amadeus data set, this data set is not a commercially exploited one and confidentiality had to be preserved.

Table 1 and 2 show a comparison of some of the key variables with the entire population. From table 1 it can be noted that the data in all three countries cover more than $60 \%$ of total sales in manufacturing. Also employment coverage is quite good, especially for Bulgaria and Romania. In table 2 a comparison between the sample and population is given for all twodigit sectors. It can be noted that sales coverage in the various sectors included in this sample is mostly quite high for the three countries. Thus, our data can be considered as fairly representative of the population of firms in manufacturing in Bulgaria, Romania and Poland.

We follow a standard approach and estimate an augmented production function as in Nickell, Nicolitsas and Dryden (1997). We use two indicators of competitive pressure: the Herfindahl concentration ratio and import penetration (see data appendix for details on measurement). We measure them at the three-digit NACE revision 1 industrial classification. Figures 1, 2 and 3 show the evolution of the mean concentration index and import penetration in the three countries. We can note how the values of these ratios are very similar for Bulgaria and Romania and that concentration has a downward trend, while import penetration is growing, suggesting that increased competition is taking place. In Poland, import penetration is on average also increasing, while on average it seems that the level of concentration is not changing much (although it actually decreases of an average level of 5\% in 1994 to an average level of $4 \%$ in 1998). The level of concentration is Poland is much 


\section{William Davidson Institute Working Paper 434}

lower than that in Bulgaria and Romania. This suggests that product markets in Polish manufacturing are far more competitive than in the two other countries, presumably because in Poland market reforms have been implemented earlier.

Table 3 shows some summary statistics of the various firm specific variables used in the analysis. We can note that the average firm in Romania employs over 600 people in 1998, while in Bulgaria this is only 384. In Poland the average firm has 149 workers in 1998. This reflects the fact that for the Polish sample we also have the smaller firms in the analysis and that restructuring in Polish firms started earlier on.

The ownership information that we have for Bulgaria and Romania is slightly different than that for Poland. For the former two countries we have information on the fraction of shares that is held by each ownership type in each year. In contrast, for Poland we only know whether a firm is a majority owned private, foreign or state firm in both years. Note from table 3 that the average fraction of shares in 1998 held by private domestic owners is $68 \%$ in Bulgaria and $50 \%$ in Romania . If we look at shareholding in private firms only we observe that private investors retain on average $81 \%$ of the total shares in private firms in Bulgaria and almost $60 \%$ in Romania. The fraction of shares held by foreign owners is only $4 \%$ on average in Bulgaria, $11 \%$ in Romania. This reflects the relative small fraction of firms that do have some foreign participation. However, if we look at the average fraction of shares held by foreign owners in firms with some foreign participation only, then the average foreign quota is larger than $60 \%$. We can also note that in all countries the fraction of private and foreign firms in total goes up over time.

In the analysis we deflated the nominal values of the relevant variables by a threedigit producer price index, which was obtained from the central statistical offices. 


\section{William Davidson Institute Working Paper 434}

\section{Results}

We estimate a standard log-linearised Cobb-Douglas production function augmented with indicators of competitive pressure and ownership variables or

$y_{i t}=\alpha_{i}+\alpha_{1} n_{i t}+\alpha_{2} k_{i t}+\alpha_{3} P R I V D_{i t}+\alpha_{4} F_{F R E I G N}+\alpha_{5} H E R F_{j t}+\alpha_{6} I M P_{j t}+\varepsilon_{i t}$

where y stands for log real value added, $\mathrm{n}$ stands for log employment, $\mathrm{k}$ stands for log of real capital (proxied by the book value of fixed assets), PRIVD stands for the fraction of shares held by private domestic owners, FOREIGN is the fraction of shares held by foreign owners in the firm at time $t$, HERF is the Herfindahl index of concentration, IMP is import penetration and $\varepsilon$ is a white noise error term. The ownership category that is left out is the state, which refers to the fraction of shares in the firm held by the government (treasury), including also the municipalities. Finally, we control for unobserved heterogeneity by including a firm level fixed effect. Subscripts i refer to firm $i, j$ refers to sector $j$ and $t$ refers to year.

We report three estimation techniques, results based on simple OLS estimates, then the fixed effects and random effects estimator. However, the Hausman test always rejected the random effects model. Tables 4, 5 and 6 report the basic equations for the three countries respectively. The first specification only considers the effects of ownership, while in the second specification we also include competitive pressure. All specifications include a year dummy to control for common aggregate shocks.

From the first column in table 4 we can note that private ownership is associated with higher total factor productivity in Bulgaria, but only in the OLS and random effects model. Once we control for unobserved fixed effects, we find no longer a statistically significant effect of domestic private ownership on firm performance in Bulgaria. However, we do find 
evidence that foreign firms perform better than private domestic firms, irrespective of the estimation technique that is used. This suggests that, whatever the direction of causality, foreign firms might have some superior knowledge, which leads them to be more efficient. The Hausman test rejects the random effect model in favour of the fixed effect one, so we should base our interpretation on the fixed effects model ${ }^{6}$. Since the ownership variable refers to the fraction of shares held by foreign investors we could interpret the magnitude of the coefficient as follows. If a fully state owned enterprise became $100 \%$ owned by foreign investors then total factor productivity would increase on average by $29 \%$.

The first column of table 5 shows the same specification for Romania. We find strong positive effects of private domestic ownership, but not of foreign ownership, whose coefficient is still positive, although not statistically different from zero. Finally, the first column of table 6 shows that also in Poland private ownership is associated with higher total factor productivity compared to non-private firms. Note that for the Polish specification the ownership variables refer to dummies reflecting majority ownership stakes. We can also note that foreign firms in Polish manufacturing not only perform better than state firms, but also better than private domestic ones. As in Bulgaria this suggests that foreign firms have some superior knowledge or expertise, which allows them to perform better than private domestic firms.

Nickell (1996) suggested that the effect of corporate governance might be reduced once the effects of competitive pressure are taken into account. The intuition is that competitive pressure leads to a higher risk of bankruptcy, which should discipline managers, irrespective of corporate governance. In the context of theoretical models that emphasize the complementarity of reforms we would expect that the direct effects of corporate governance

\footnotetext{
${ }^{6}$ A critique to the use of within-group estimation is that the assumption of a time-invariant fixed effect correlated to the exogenous variables does not allow doing any out-of-sample inference, i.e. the results obtained are only valid for the sample used. However, given the size of our samples and the high coverage of mediumlarge sized manufacturing firms, we believe such critique does not apply to the present results.
} 
and competitive pressure may not be so high, but rather the interaction between ownership changes and competitive pressure should lead to have an impact on firm performance. In other words, increased competitive pressure may have very little effects when firms are state owned as bankruptcy is less of an option. We develop this idea by looking not only at the direct effects of competitive pressure, but also at the interactions with ownership changes.

In column (2) of tables 4-6 we start by including our measures of competitive pressure, without any interaction terms with ownership structure. Again, focusing on the results of the fixed effects estimation, we find that the same effects of ownership structure in the three countries are robust to the inclusion of concentration and import penetration in the specification. However, we find no effects of concentration on total factor productivity in Bulgaria. For Romania and Poland we do find strong negative effects of concentration on total factor productivity. Thus, it seems that competitive pressure as measured by product market concentration does not lead to higher performance in Bulgaria, but it does so in Romania and Poland. A rather puzzling result emerges when we look at the effects of import penetration. The effect of import penetration is negative and statistically significant in Bulgaria and Romania, while in Poland it has the expected sign. We will offer an explanation for this finding later on.

In tables 7 and 8 we experimented with interactions between ownership and competitive pressure. By doing this we test whether competitive pressure has different effects in privatised firms than in state firms. Or to put it differently, we test whether privatisation has different effects in highly competitive sectors compared to sectors where competition is low. In table 7 we report results for Bulgaria and Romania, while in table 8 we also report results for Poland.

We focus on the results of the fixed effects model because the Hausman test always rejects the random effects model. In the third column of table 7 we can note that for Bulgaria 


\section{William Davidson Institute Working Paper 434}

the direct effects of private domestic ownership and foreign ownership are large, positive and statistically significant. The interaction between ownership and the Herfindahl index is negative and significant, but only for private domestic firms, while the direct effect of concentration is positive. We can also note that the effect of domestic privately owned firms now becomes statistically significant. These results can be interpreted in two ways. First, private ownership is associated with higher firm performance, however, this positive effect diminishes in sectors that are less competitive. In fact, for sectors with a Herfindahl index larger than $36 \%$ the effect of privatisation is a negative one. This confirms the existence of complementarities between ownership and competition. Privatisation only works if there exists enough competitive pressure or in other words if markets work. The interaction effect for foreign firms, however, is not statistically significant, which suggests that the effect of foreign ownership is the same irrespective of the market structure in Bulgaria. This may be the case if foreign firms operate mostly in international, competitive markets and enter into competitive markets. Alternatively, we could say that competitive pressure is more likely to work in privatised firms. Based on the estimates, firms with at least $86 \%$ of the shares in private hands will experience positive effects of increased competitive pressure. The average shareholding in private firms that are private is $80 \%$ in Bulgaria, so most private firms are associated with positive effects of increased competitive pressure. This result makes sense since state firms can typically be bailed out by the government if they make losses. In other words, the threat of bankruptcy for such firms is of lesser importance. Note also that import penetration is no longer statistically significant once we include the interaction effects with ownership. We also experimented, but not reported here, with including industry sales as one of the regressors to control for market size. Results on ownership and competitive pressure are robust to the inclusion of industry sales. 
The results for Romania are slightly different. From column (3) in table 7 we note that the direct ownership effects are no longer statistically significant. Concentration has a strong negative effect, which suggests that increased competitive pressure is associated with higher total factor productivity. However, import penetration has a negative effect. Furthermore, the interaction terms are not statistically significant.

The analysis so far only took into account the ownership structure of firms, without making a distinction between majority owned private and foreign firms. The fact that we find that the effect of ownership in Romania is weaker and that we find no complementarities between ownership changes and competitive pressure, may be due to a large proportion of firms where the state has still a large stake in the firm and that therefore restructuring may be postponed. In table 8 we therefore report the same set of regressions but then for ownership categories defined according to a majority stake in the firm? ${ }^{7}$. In this way, we can compare the effects of competition on different ownership groups. Furthermore, this specification permits to compare directly the results for Bulgaria and Romania with the Polish ones, as only ownership dummies are available for this last country. We only report fixed effects estimates. The Hausman test always rejected the random effects model, although the estimated coefficients are quite similar in sign and significance.

Our main results remain robust to restraining the analysis to majority ownership groups only. In Bulgaria we can note that majority foreign owned firms always outperform majority owned private domestic firms and they both outperform majority owned state firms. Again, we find evidence for positive effects of competitive pressure as measured by product market concentration, but only in privatised firms. We can also note that import penetration has a negative effect on firm performance, but only in privatised firms. The results for Romania are also similar to the ones that we reported in table 7. Ownership does not seem to 
contribute much to total factor productivity, rather competitive pressure as measured by product market concentration is the single most important factor that affects firm performance. However, also here the negative effect of import competition remains statistically significant.

The results for Poland indicate that private domestic firms and foreign firms outperform state owned enterprises. Furthermore, import penetration and more competitive market structures are associated with higher total factor productivity. The interaction effects indicate that the effects of product market concentration feed mainly through foreign firms, rather than domestic private ones. The same holds for import penetration. Thus the disciplining effects of competitive pressure in Poland are reinforced in foreign owned firms.

This re-asserts the conclusion that had been reached when analysing Bulgarian data: at some point in the transition process, the interplay between competition and private ownership is an important factor for the achievement of higher productivity. In Poland the leading role is played by foreign-owned firms. Such outcome is not surprising: whatever the direction of causality, it is likely that total factor productivity is highest for these enterprises. Foreign-owned firms are then expected to benefit more from the pressure exerted by competition.

This latter point may suggest a different interpretation of the results. A possible reason why domestic competition is associated with higher productivity in all countries (at least for private-owned firms), while import competition is not, may depend on the initial technological and efficiency differentials between firms operating in the same markets. If competition between similarly productive and technologically advanced firms might eventually lead to restructuring and to improved performance, the presence of much better firms in the same market may discourage enterprise restructuring. Imports may come from

\footnotetext{
${ }^{7}$ Technically speaking, instead of using continuous shareholding variables ranging between zero and one, we
} 


\section{William Davidson Institute Working Paper 434}

firms with a large positive efficiency differential. Both in Bulgaria and Romania, which lag behind in the transition process, competition from imports is associated with lower total factor productivity. Competition may feed through a selection mechanism where in the short run firms have increasingly less resources to implement restructuring, which may lead to exit in the long run. In constrast, Polish firms went through an initial restructuring phase, which allows them to compete in world markets.

\section{Conclusion}

This paper used a unique firm level panel data set to analyse the effects of ownership and competitive pressure on firm performance in three Central European countries. Two of them are lagging behind in the transition process, with relatively weak institutions and slow paced market oriented reforms, while the third one is more advanced. After controlling for firm level heterogeneity we find that privatisation is associated with better firm performance, measured by total factor productivity. The effects of ownership become somewhat weaker in Romania once we take into account interactions between ownership and competitive pressure. Moreover, we find evidence that in Bulgaria foreign owned firms outperform domestic privately owned firms, and that in Poland all private-owned firms achieve higher productivity levels than state-owned ones. We do not find this result in Romania.

Apart from the effects of ownership we find evidence that domestic competitive pressure is associated with better firm performance, especially in the more advanced transition country, Poland. Moreover, for Bulgaria we report evidence that domestic competitive pressure has only a disciplining effect in privatised firms, not in state firms. In Romania we find that domestic competitive pressure is associated with higher performance irrespective of ownership. However, increased import competition is associated with lower 


\section{William Davidson Institute Working Paper 434}

total factor productivity in Bulgaria and Romania, while the opposite result holds in Poland . This suggests that foreign import competing firms are far more efficient than domestic firms in Bulgaria and Romania, where restructuring has been postponed. If the technology gap is too wide between domestic firms and importers from abroad, then the presence of much better firms in the same market may discourage enterprise restructuring. Imports may come from firms with a large positive efficiency differential.

If this were the case, though, the order and pace of reforms should be carefully administered. It should be insured that the intensity of competition from technologically advanced firms does not limit the productivity growth triggered by other reforms. Instead, internal competition should be encouraged from the early stages of transition, making sure it reinforces the beneficial effect that sound governance has on firm performance. 
William Davidson Institute Working Paper 434

Table 1: Comparison between Amadeus and National Statistics, 1998

\begin{tabular}{l|lll}
\hline & Bulgaria & Romania & Poland \\
\hline Employment coverage & .66 & .70 & .42 \\
Sales Coverage & .82 & .69 & .64 \\
\hline
\end{tabular}

Note: Sales coverage ratio = total sales in Amadeus / total national sales. Employment coverage ratio $=$ total employment in Amadeus / total national employment.

Note: database for Poland based on F-02 questionnaire (covers all manufacturing enterprises operating both in 1994 and 1998) 
Table 2: Sales industry coverage using Amadeus data set, 1998

\begin{tabular}{l|lll}
\hline Industry code & Bulgaria & Romania & Poland \\
\hline 15 & .51 & .60 & .58 \\
16 & .80 & .96 & .35 \\
17 & 1 & .87 & .55 \\
18 & .44 & .51 & .60 \\
19 & .57 & .54 & .53 \\
20 & .51 & .41 & .41 \\
21 & .76 & .75 & .19 \\
22 & .55 & .30 & .53 \\
23 & - & 1 & .52 \\
24 & .98 & .69 & .66 \\
25 & .55 & .84 & .37 \\
26 & .74 & .79 & .60 \\
27 & 1 & .45 & .52 \\
28 & .56 & .51 & .53 \\
29 & .64 & .76 & .57 \\
30 & .23 & .88 & .79 \\
31 & 1 & .63 & .61 \\
32 & 1 & .52 & .60 \\
33 & .50 & .67 & .70 \\
34 & .67 & .93 & .56 \\
35 & .87 & .68 & .65 \\
36 & .43 & .61 & .61 \\
37 & - & .75 & .60 \\
\hline
\end{tabular}

Note: Sales coverage ratio $=$ total industry sales in the data set / total national industry sales according to the 2-digit NACE industry classification. For Bulgaria, data on national industry sales are not available in sectors 23 and 37. 
Table 3: Summary Statistics of the firm specific variables used in the analysis

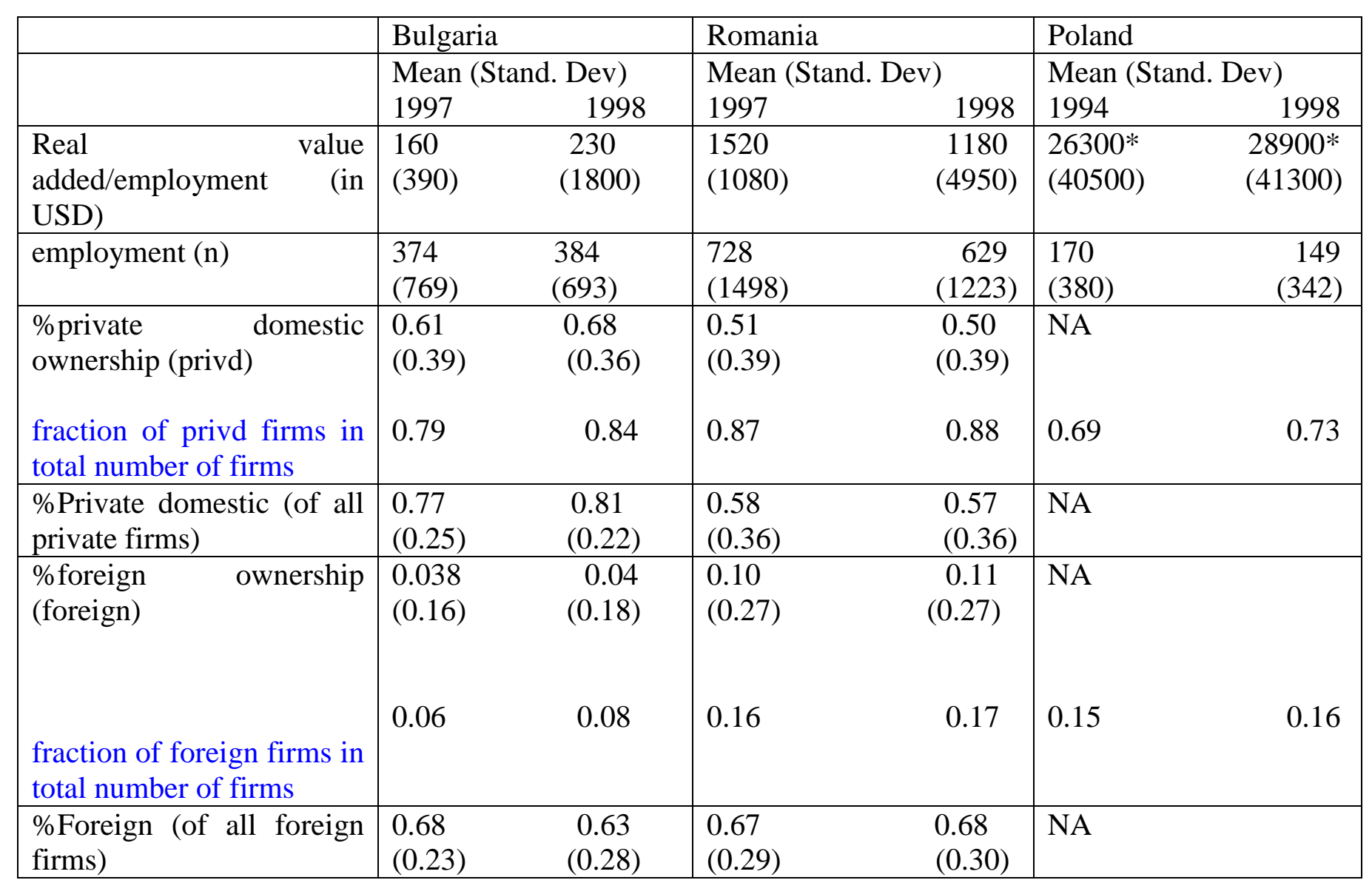

Notes: * refers to real sales, rather than value added; NA refers to non available 
William Davidson Institute Working Paper 434

Table 4: Effect of ownership, concentration and import penetration on performance in Bulgaria

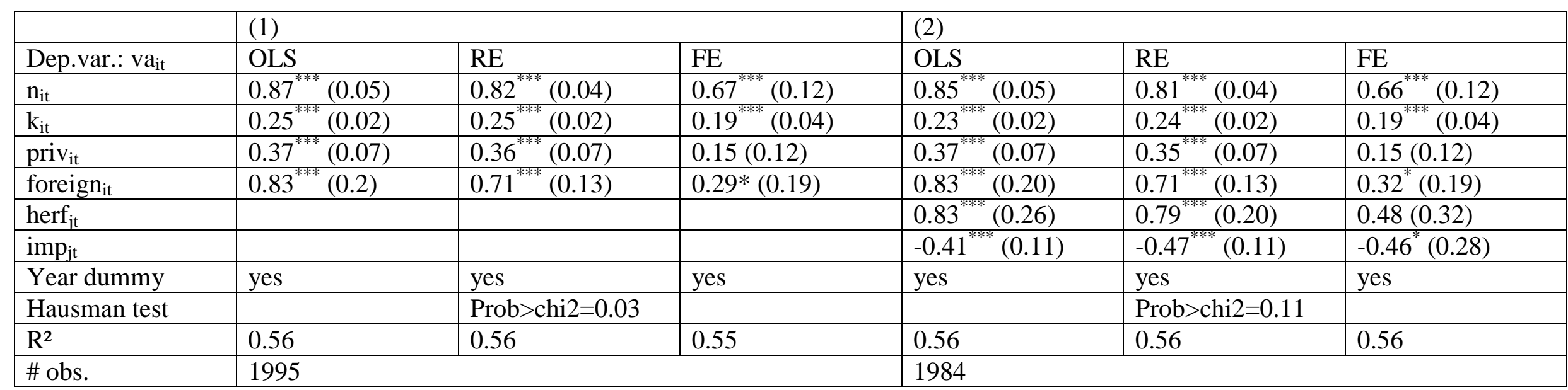

Note: robust standard error in parentheses, $* * * / * * *$ denote statistical significance at $1 \% / 5 \% / 10 \%$; overall $\mathrm{R}^{2}$ in the random and fixed effects specifications 
William Davidson Institute Working Paper 434

Table 5: Effect of ownership, concentration and import penetration on performance in Romania

\begin{tabular}{|c|c|c|c|c|c|c|}
\hline & \multicolumn{3}{|l|}{ (1) } & \multicolumn{3}{|l|}{ (2) } \\
\hline Dep.var.: va $\mathrm{it}_{\mathrm{it}}$ & OLS & $\mathrm{RE}$ & $\mathrm{FE}$ & OLS & $\mathrm{RE}$ & $\mathrm{FE}$ \\
\hline $\mathrm{n}_{\text {it }}$ & $0.78^{\text {**** }}(0.03)$ & $0.79^{* * *}(0.02)$ & $0.68^{\text {***** }}(0.06)$ & $0.77^{* * *}(0.03)$ & $0.79^{* * *}(0.02)$ & $0.67^{\text {*** }}(0.06)$ \\
\hline $\mathrm{k}_{\mathrm{it}}$ & $0.25^{\text {**** }}(0.02)$ & $0.21^{\text {*** }}(0.01)$ & $0.11^{* * * *}(0.03)$ & $0.24^{* * *}(0.02)$ & $0.21^{* * *}(0.01)$ & $0.11^{\text {*** }}(0.03)$ \\
\hline priv $_{\text {it }}$ & $0.85^{\text {**** }}(0.05)$ & $0.76^{\text {**** }}(0.05)$ & $0.31^{* *}(0.14)$ & $0.86^{* * * *}(0.05)$ & $0.76^{* * * *}(0.05)$ & $0.30^{* *}(0.14)$ \\
\hline foreign $_{i t}$ & $1.37^{\text {**** }}(0.07)$ & $1.31^{\text {*** }}(0.07)$ & $0.09(0.35)$ & $1.38^{* * * *}(0.07)$ & $1.31^{\text {*** }}(0.07)$ & $0.09(0.35)$ \\
\hline herf $_{j t}$ & & & & $0.63^{* * *}(0.22)$ & $0.35(0.23)$ & $-1.91^{\text {*** }}(0.50)$ \\
\hline $\mathrm{imp}_{\mathrm{jt}}$ & & & & $-0.28^{* * *}(0.10)$ & $-0.31^{* * *}(0.09)$ & $-0.60^{* *}(0.29)$ \\
\hline Year dummy & yes & yes & yes & yes & yes & Yes \\
\hline Hausman test & & Prob $>$ chi $2=0.00$ & & & Prob $>$ chi $2=0.00$ & \\
\hline $\mathrm{R}^{2}$ & 0.63 & 0.63 & 0.57 & 0.63 & 0.63 & 0.53 \\
\hline \# obs. & \multicolumn{3}{|l|}{3002} & \multicolumn{3}{|l|}{2942} \\
\hline
\end{tabular}

Note: see table 4 
Table 6: Effects of ownership, concentration and import penetration on firm performance in Poland

\begin{tabular}{|c|c|c|c|c|c|c|}
\hline & \multicolumn{3}{|c|}{ (1) } & \multicolumn{3}{|c|}{ (2) } \\
\hline Dep.var.: sales ${ }_{\text {it }}$ & OLS & $\mathrm{RE}$ & $\mathrm{FE}$ & OLS & $\mathrm{RE}$ & FE \\
\hline $\mathrm{n}_{\mathrm{i}, \mathrm{t}}$ & $\begin{array}{l}0.66^{* * * *} \\
(0.008)\end{array}$ & $0.69^{* * * *}(0.007)$ & $\begin{array}{l}0.74^{* * * *} \\
(0.011)\end{array}$ & $\begin{array}{l}0.66^{* * * *} \\
(0.008)\end{array}$ & $0.69^{* * * *}(0.008)$ & $0.75^{* * * *}(0.011)$ \\
\hline $\mathrm{k}_{\mathrm{i}, \mathrm{t}}$ & $\begin{array}{l}0.26^{* 3 * * * 3} \\
(0.005)\end{array}$ & $0.23^{* * * *}(.005)$ & $\begin{array}{l}0.16^{* * 3 * *} \\
(0.008)\end{array}$ & $\begin{array}{l}0.26^{2 * 3 *} \\
(0.005)\end{array}$ & $0.23^{* * * * *}(0.005)$ & $0.16^{* * * * *}(0.008)$ \\
\hline $\operatorname{priv}_{\mathrm{i}, \mathrm{t}}$ & $\begin{array}{l}0.26^{* * * * *} \\
(0.022)\end{array}$ & $0.30^{* * * * *}(0.027)$ & $\begin{array}{l}0.28^{* * * * *} \\
(0.050)\end{array}$ & $\begin{array}{l}0.24^{* * * *} \\
(0.023\end{array}$ & $0.32^{* * * * *}(0.027)$ & $0.26^{* * * *}(0.050)$ \\
\hline foreign $_{i, t}$ & $\begin{array}{l}0.39^{* 3 * * *} \\
(0.027)\end{array}$ & $0.44^{* * * * *}(0.034)$ & $\begin{array}{l}0.30^{* * * * *} \\
(0.071)\end{array}$ & $\begin{array}{l}0.37^{* * * * *} \\
(0.028)\end{array}$ & $0.46^{* * * *}(0.03)$ & $0.29^{* * * *}(0.071)$ \\
\hline $\operatorname{herf}_{\mathrm{j}, \mathrm{t}}$ & & & & $\begin{array}{l}0.30^{* * * * *} \\
(0.101)\end{array}$ & $2.08^{* * * *}(0.26)$ & $-1.39^{* * *}(0.63)$ \\
\hline $\mathrm{imp}_{\mathrm{j}, \mathrm{t}}$ & & & & $\begin{array}{l}-0.22^{* * * *} \\
(0.048) \\
\end{array}$ & $-0.25^{* * * *}(0.06)$ & $0.62^{* * * * *}(0.17)$ \\
\hline Year dummy & yes & yes & yes & yes & yes & yes \\
\hline Hausman test & & $\begin{array}{c}\text { Prob }>\text { chi } 2=0.00 \\
0\end{array}$ & & & $\begin{array}{c}\text { Prob }>\text { chi } 2=0.00 \\
0\end{array}$ & \\
\hline $\mathrm{R}^{2}$ & 0.70 & 0.70 & 0.69 & 0.70 & 0.70 & 0.69 \\
\hline \# obs. & & & & 570 & & \\
\hline
\end{tabular}

Note: see table 4 
Table 7: Effect of ownership, concentration, import penetration and interactions on performance in Bulgaria and Romania

\begin{tabular}{|c|c|c|c|c|c|c|}
\hline \multirow[b]{2}{*}{ Dep.var.: va $\mathrm{i}_{\mathrm{it}}$} & \multicolumn{3}{|l|}{ Bulgaria } & \multicolumn{3}{|l|}{ Romania } \\
\hline & OLS & $\mathrm{RE}$ & $\mathrm{FE}$ & OLS & $\mathrm{RE}$ & $\mathrm{FE}$ \\
\hline $\mathrm{n}_{\mathrm{it}}$ & $0.86^{\text {***** }}(0.05)$ & $0.81^{* * * *}(0.04)$ & $0.67^{* * * *}(0.12)$ & $0.78^{* * * *}(0.03)$ & $0.79^{* * * *}(0.02)$ & $0.67^{* * * *}(0.06)$ \\
\hline $\mathrm{k}_{\mathrm{it}}$ & $0.23^{* * * *}(0.02)$ & $0.24^{* * * *}(0.02)$ & $0.19^{* * * *}(0.04)$ & $0.24^{* * * *}(0.02)$ & $0.20^{* * * *}(0.01)$ & $0.11^{\text {***** }}(0.03)$ \\
\hline privit $_{\text {it }}$ & $0.40^{* * * *}(0.14)$ & $0.51^{* * * *}(0.11)$ & $0.48^{* * * *}(0.18)$ & $0.77^{* * * *}(0.09)$ & $0.67^{* * * *}(0.08)$ & $0.22(0.22)$ \\
\hline foreign $_{\mathrm{it}}$ & $1.71^{* * * *}(0.30)$ & $1.14^{* * * *}(0.20)$ & $0.57^{* *}(0.27)$ & $1.33^{* * *}(0.13)$ & $1.18^{* * * *}(0.13)$ & $-0.46(0.49)$ \\
\hline herf $_{\mathrm{jt}}$ & $0.62^{*}(0.36)$ & $1.19^{* * * *}(0.33)$ & $1.13^{* *}(0.46)$ & $-0.16(0.31)$ & $-0.39(0.34)$ & $-2.62^{* * * *}(0.76)$ \\
\hline $\mathrm{imp}_{\mathrm{jt}}$ & $-0.12(0.19)$ & $-0.21(0.20)$ & $-0.32(0.37)$ & $-0.25(0.15)$ & $-0.33^{* * *}(0.14)$ & $-0.68^{*}(0.39)$ \\
\hline herf $_{\mathrm{jt}} * \operatorname{priv}_{\mathrm{it}}$ & $0.55(0.52)$ & $-0.60(0.41)$ & $-1.30^{* * *}(0.53)$ & $1.71^{* * * *}(0.62)$ & $1.44^{* *}(0.58)$ & $1.15(1.10)$ \\
\hline herf $_{\mathrm{jt}} *$ foreign $_{\mathrm{it}}$ & $-1.83(1.63)$ & $-0.86(0.94)$ & $-0.73(1.18)$ & $2.32^{* *}(0.96)$ & $2.47^{* * * *}(0.95)$ & $2.86(2.14)$ \\
\hline $\operatorname{imp}_{\mathrm{it}}{ }^{*}$ priv $_{\mathrm{it}}$ & $-0.29(0.26)$ & $-0.32(0.26)$ & $-0.40(0.42)$ & $-0.10(0.26)$ & $-0.02(0.22)$ & $-0.03(0.49)$ \\
\hline $\mathrm{imp}_{\mathrm{jt}} *$ foreign $_{\mathrm{it}}$ & $\begin{array}{l}-2.44^{* * * *} \\
(0.84)\end{array}$ & $-1.25^{* * *}(0.57)$ & $-0.51(0.81)$ & $-0.31(0.45)$ & $-0.06(0.39)$ & $1.04(0.92)$ \\
\hline Year dummy & Yes & yes & yes & yes & yes & yes \\
\hline Hausman test & & $\begin{array}{l}\text { Prob }>\text { chi } 2=0 . \\
00\end{array}$ & & & $\begin{array}{l}\text { Prob }>\text { chi } 2=0 . \\
00\end{array}$ & \\
\hline $\mathrm{R}^{2}$ & 0.57 & 0.57 & 0.55 & 0.64 & 0.63 & 0.51 \\
\hline \# obs. & 1984 & & & 2942 & & \\
\hline
\end{tabular}

Note: see table 4 
Table 8: Effect of majority ownership, concentration, import penetration and interactions on performance in Bulgaria, Romania and Poland

\begin{tabular}{|c|c|c|c|}
\hline & Bulgaria & Romania & Poland \\
\hline Dep.var.: va $a_{i t}$ & FE (majority owned firms) & FE (majority owned firms) & FE (majority owned firms) \\
\hline $\mathrm{n}_{\mathrm{it}}$ & $0.66^{* * * *}(0.12$ & $0.67^{* * * *}(0.06)$ & $0.74^{* * * *}(0.011)$ \\
\hline $\mathrm{k}_{\mathrm{it}}$ & $0.19^{* * * *}(0.04)$ & $0.11^{* * * *}(0.03)$ & $0.16^{* * * *}(0.008)$ \\
\hline priv $_{\text {it }}$ & $0.28^{* *}(0.13)$ & $0.05(0.16)$ & $0.30^{* * * *}(0.072)$ \\
\hline foreign $_{\text {it }}$ & $0.39^{*}(0.21)$ & $-0.55(0.38)$ & $0.27^{* * *}(0.105)$ \\
\hline herf $_{\text {jt }}$ & $0.84^{*}(0.43)$ & $-2.51^{* * *}(0.60)$ & $-1.30 *(0.89)$ \\
\hline $\mathrm{imp}_{\mathrm{jt}}$ & $-0.06(0.33)$ & $-0.69^{* * *}(0.34)$ & $0.71^{\text {*** }}(0.255)$ \\
\hline herf $_{\text {jt }} *$ priv $_{\mathrm{it}}$ & $-0.76^{*}(0.41)$ & $1.21(0.75)$ & $0.70(0.83)$ \\
\hline herf $_{\text {jt }}{ }^{*}$ foreign $_{\mathrm{it}}$ & $-0.23(0.83)$ & $2.01(1.60)$ & $-3.47^{* * * * *}(1.181)$ \\
\hline $\operatorname{imp}_{\mathrm{jt}}{ }^{*}$ priv $_{\mathrm{it}}$ & $-0.58^{*}(0.32)$ & $-0.01(0.33)$ & $-0.24(0.22)$ \\
\hline $\mathrm{imp}_{\mathrm{jt}}{ }^{*}$ foreign $\mathrm{it}_{\mathrm{it}}$ & $-1.00^{*}(0.59)$ & $0.87(0.70)$ & $0.58^{*}(0.314)$ \\
\hline Year dummy & Yes & Yes & Yes \\
\hline $\mathrm{R}^{2}$ & 0.55 & 0.48 & 0.69 \\
\hline \# obs. & 1984 & 2942 & 17570 \\
\hline
\end{tabular}

Note: see table 4 


\section{William Davidson Institute Working Paper 434}

\section{Appendix}

\section{Data Appendix}

The data are company accounts data and were retrieved from the Romanian Chambers of Commerce and Industry for Romania and from Creditreform Bulgaria OOD for Bulgaria. The company accounts were made consistent, using uniform accounting methods, by Bureau Van Dijck to allow cross country comparisons of company accounts.

For Poland, the data refer to enterprises in manufacturing, 1994 and 1998, based on F-02 and SP statistical questionnaires. The data come from the statistical office and is confidential.

The data used in the analysis are measures as follows

\section{$\underline{\text { Firm Specific Data }}$}

value added: sales minus material costs

employment: total number of employed people at the end of the year

capital: book value of fixed capital

The data are deflated with a three digit producer price index

\section{Construction of ownership data}

The ownership structure for each firm in the data is provided. In particular, for each firm the name of each individual owner is given and the fraction of shares that is owned by that owner. We defined three groups of broad ownership categories: state, private domestic and foreign. Typically, in the state category we include shares held by the Treasury, by communities and municipalities. We were able to identify foreign owned firms based on the name of the owner (a foreign firm). In addition, the data provide information whether the company is a subsidiary of a multinational enterprise. The residual ownership category is then called the private domestic owners. The firms for which we did not obtain ownership information were not included in the analysis. Thus we have three ownership categories: 
private domestic owners: fraction of shares held by private domestic investors foreign owners: fraction of shares held by foreign owners state owned: fraction of shares held by the state, municipalities or Treasury.

The sector level data were retrieved from and computed by the statistical offices: Herfindahl index: sum of the squared market shares at the three digit NACE, revision 1 level import penetration: imports/(industy sales+imports) at the three digit NACE, revision 1 level producer price index: a three digit producer price index, normalized to 1 in 1995. 


\section{References:}

Blanchflower, D. and Machin, S. (1996). “"Product Market Competition, Wages and Productivity: International Evidence from Establishment Level Data", Centre for Economic Performance, LSE, DP 286.

Brown, J. and Earle, J. (2000a). "Competition and Firm Performance: Lessons from Russia", CEPR Discussion Paper 2444.

Brown, J. and Earle, J. (2000b). "Privatization, Competition and Transition Policy Strategies: Theory and Evidence from Russian Enterprise Panel Data", Mimeo SITE Stockholm.

Carlin, W., Fries, S., Schaffer, M. and Seabright, P. (2001). "Competition and Enterprise Performance in Transition Economies: Evidence from a Cross-Country Survey", Working Paper William Davidson Institute, University of Michigan, Ann Arbor.

Dewatripont, M. and Roland, G. (1992). "Economic Reform and Dynamic Political Constraints", Review of Economic Studies, 62, pp. 541-555.

Djankov, S. and Hoekman, B. (1998). "Avenues of Technology Transfer: Foreign Investment and Productivity Change in the Czech Republic", CEPR discussion paper 1883.

Earle, J. and Estrin, S. (1996). "Privatisation versus Competition: Changing Enterprise Behaviour in Russia”, CEP discussion paper 316, LSE.

Estrin, S. (2001). "Competition and Corporate Governance in Transition", Journal of Economic Perspectives, forthcoming.

EBRD (2000). “Transition Report 2000”, London, EBRD

Fingleton, J., Fox, E., Neven, D. and Seabright, P. (1996). Competition Policy and the Transformation of Central Europe, London, Centre for Economic Policy Research.

Frydman, R., Gray, C., Hessel, M., and Rapaczynski, A. (1999). "When Does Privatization Work? The Impact of Private Ownership on Corporate Performance in Transition Countries", Quarterly Journal of Economics, Vol. CXIV, issue 4, pp. 1153-1193.

Grosfeld, I. and Tressel, T. (2001). "Competition and Corporate Governance: Substitutes or Complements? Evidence from the Warsaw Stock Exchange", WDI working paper 369.

Hersch, P.; Kemme, D. and Bhandari, S. (1993). "Competition in Transition Economies: Determinants of Price-Cost Margins in Private Sector Manufacturing in Eastern Europe", Southern Economic Journal, pp. 356-66.

Konings, J.(1997). “Competition and Firm Performance in Transition Economies: Evidence from Firm Level Surveys in Slovenia, Hungary and Romania”, CEPR discussion paper 1770. 
Lizal, L. and Svejnar, J. (2001). "Investment, Credit Rationing and the Soft Budget Constraint: Evidence from Czech Panel Data", The Review of Economics and Statistics, forthcoming.

Nellis, J. (1999). “Time to Rethink Privatization in Transition Economies?", Intenational Finance Corporation, DP 38

Nickell, S. (1996). "Competition and Corporate Performance", Journal of Political Economy, vol. 104, pp. 724-746.

Nickell, S., Nicolitsas, D, and Dryden, N. (1997). "What Makes Firms Perform Well?" European Economic Review, Vol. 41, pp. 783-796.

Roland, G. (2000). Transition and Economics: Politics, Markets and Firms, MIT press. 
William Davidson Institute Working Paper 434

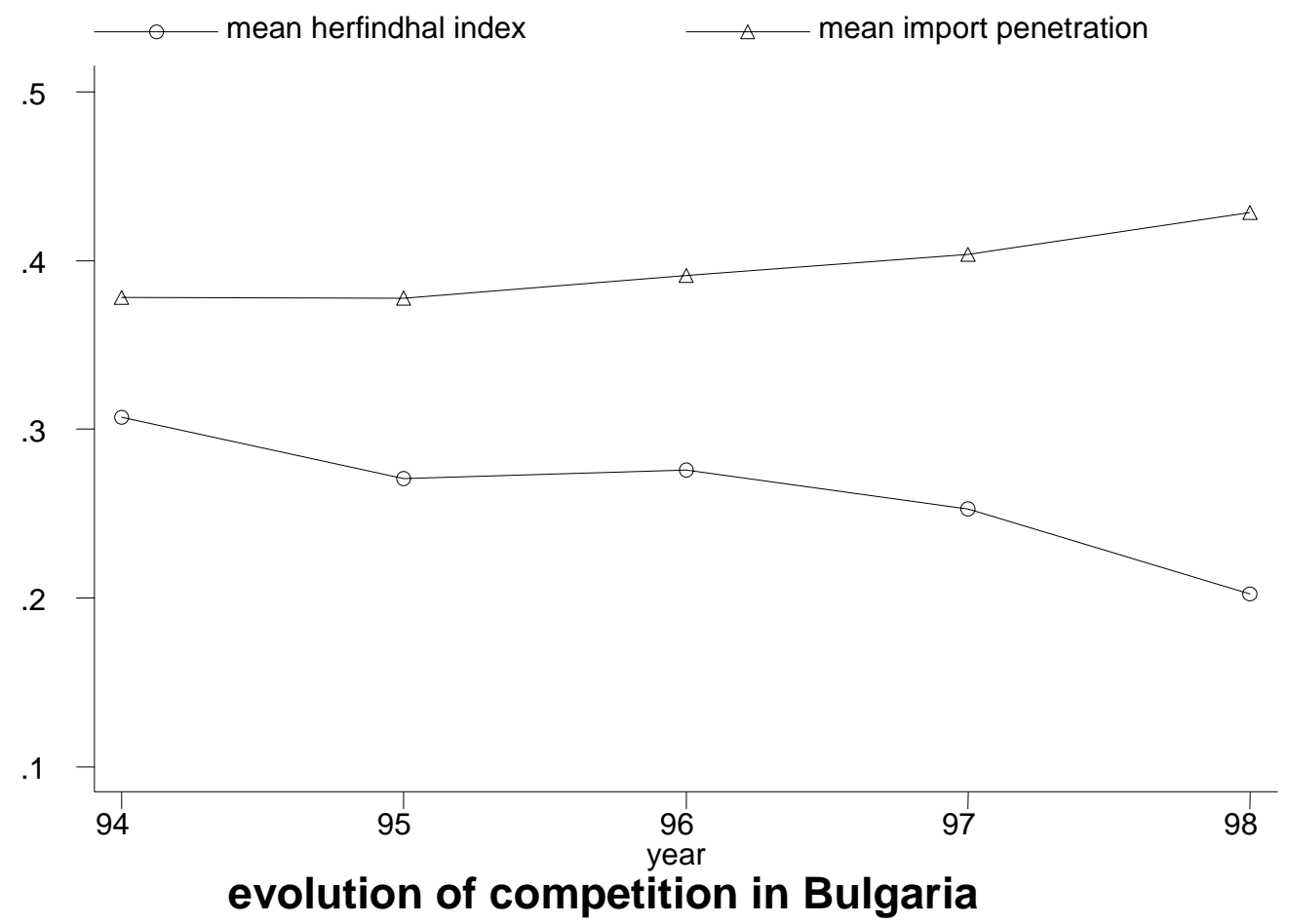

Figure 1 
William Davidson Institute Working Paper 434

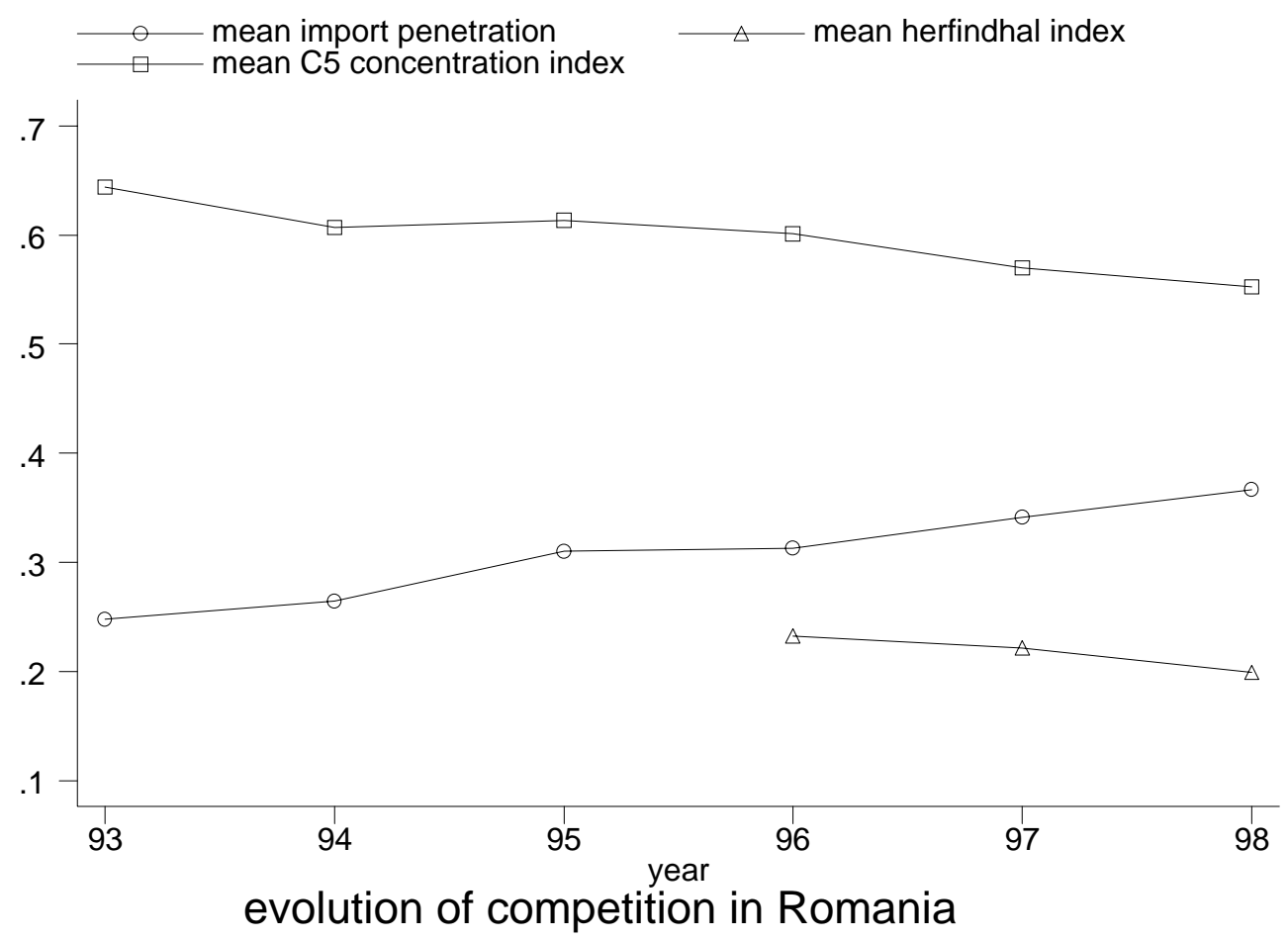

Figure 2 
William Davidson Institute Working Paper 434

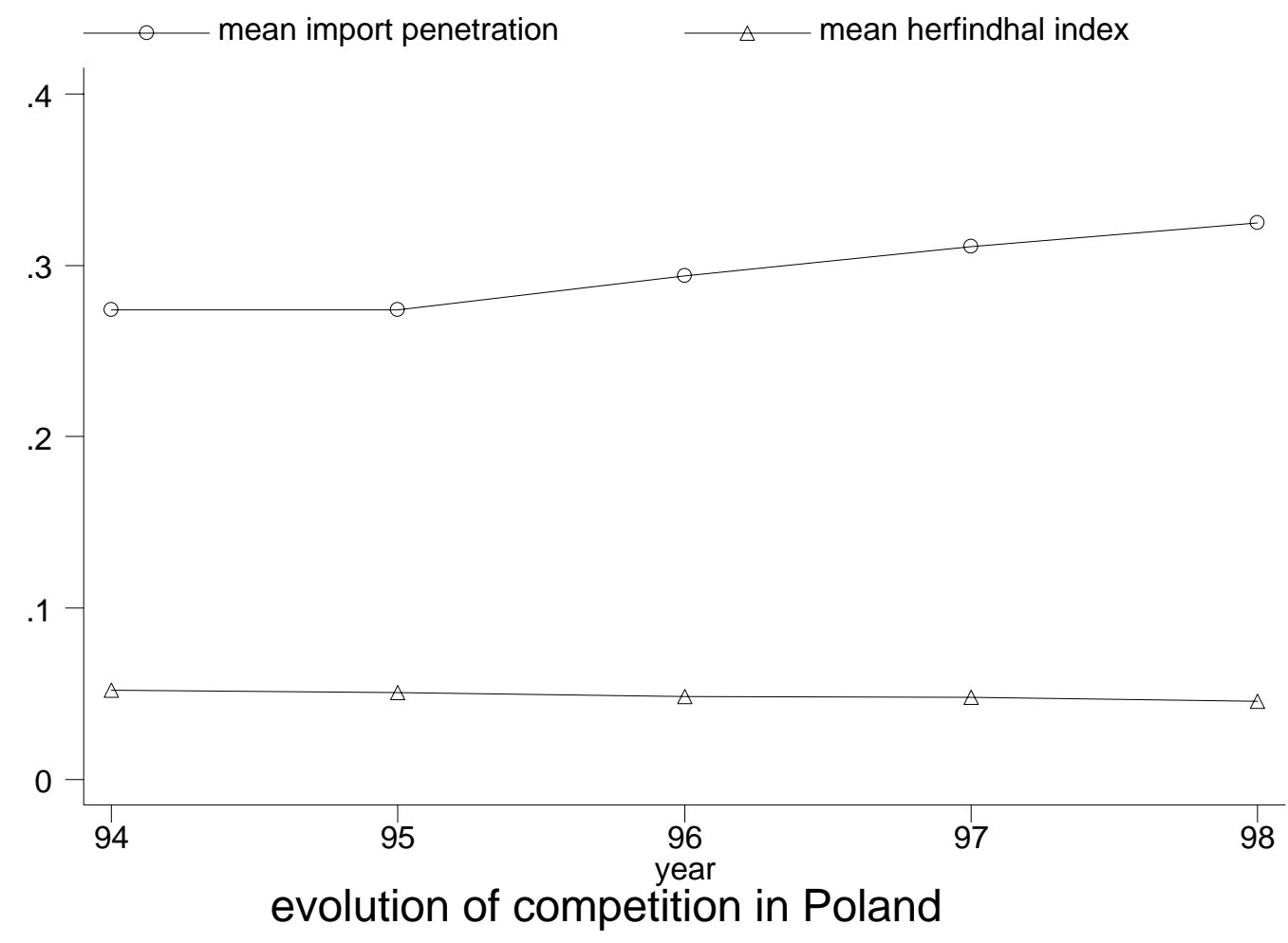

Figure 3 


\section{DAVIDSON INSTITUTE WORKING PAPER SERIES - Most Recent Papers}

The entire Working Paper Series may be downloaded free of charge at: www.wdi.bus.umich.edu

CURRENT AS OF 2/13/02

\begin{tabular}{|c|c|c|}
\hline Publication & Authors & Date \\
\hline $\begin{array}{l}\text { No. 434: The Effect of Ownership and Competitive Pressure on Firm } \\
\text { Performance in Transition Countries: Micro Evidence from Bulgaria, } \\
\text { Romania and Poland }\end{array}$ & $\begin{array}{l}\text { Manuela Angelucci, Saul Estrin, } \\
\text { Jozef Konings, Zbigniew } \\
\text { Zolkiewski }\end{array}$ & Jan. 2002 \\
\hline No. 433: The End of Moderate Inflation in Three Transition Economies? & Josef C. Brada and Ali M. Kutan & Jan. 2002 \\
\hline $\begin{array}{l}\text { No. 432: What Drives the Speed of Job Reallocation During Episodes of } \\
\text { Massive Adjustment? }\end{array}$ & $\begin{array}{l}\text { Stepan Jurajda and Katherine } \\
\text { Terrell }\end{array}$ & Jan. 2002 \\
\hline $\begin{array}{l}\text { No. } 431 \text { Forthcoming in: The Journal of Economic Perspectives, } \\
\text { "Competition and Corporate Governance in Transition," 16(2) Feb. } \\
2002 .\end{array}$ & Saul Estrin & Dec. 2001 \\
\hline $\begin{array}{l}\text { No. 430: Corporate Governance in the Cause of Peace: An } \\
\text { Environmental Perspective }\end{array}$ & Don Mayer & Jan. 2002 \\
\hline No. 429: Why do Governments Privatize? & $\begin{array}{l}\text { Loren Brandt, Hongbin Li, and } \\
\text { Joanne Roberts }\end{array}$ & Dec. 2001 \\
\hline No. 428: Testing Russia's Virtual Economy & Vlad Ivanenko & Dec. 2001 \\
\hline No. 427: War and the Business Corporation & Eric W. Orts & Dec. 2001 \\
\hline $\begin{array}{l}\text { No. 426: Partial Privatization and Firm Performance: Evidence from } \\
\text { India }\end{array}$ & Nandini Gupta & Dec. 2001 \\
\hline $\begin{array}{l}\text { No. 425: Direct Foreign Investments and Productivity Growth in } \\
\text { Hungarian Firms, 1992-1999 }\end{array}$ & Jérôme Sgard & Nov. 2001 \\
\hline $\begin{array}{l}\text { No. 424: Banking Passivity and Regulatory Failure in Emerging } \\
\text { Markets: Theory and Evidence from the Czech republic. }\end{array}$ & Jan Hanousek and Gerard Roland & July 2001 \\
\hline $\begin{array}{l}\text { No. 423: Conceptions of the Corporation and the Prospects of } \\
\text { Sustainable Peace }\end{array}$ & Jeffrey Nesteruk & Dec. 2001 \\
\hline No. 422: The Role of the Corporation in Fostering Sustainable Peace & Timothy Fort and Cindy Schipani & Nov. 2001 \\
\hline No. 421: Wage Arrears and the Distribution of Earnings in Russia & $\begin{array}{l}\text { Hartmut Lehmann and Jonathan } \\
\text { Wadsworth }\end{array}$ & Dec. 2001 \\
\hline $\begin{array}{l}\text { No. 420: Transferring Collective Knowledge: Collective and } \\
\text { Fragmented Teaching and Learning in the Chinese Auto Industry }\end{array}$ & $\begin{array}{l}\text { Jane Zhou, Jaideep Anand, and } \\
\text { Will Mitchell }\end{array}$ & Dec. 2001 \\
\hline $\begin{array}{l}\text { No. 419: Liberalization, Corporate Governance, and the Performance of } \\
\text { Newly Privatized Firms }\end{array}$ & $\begin{array}{l}\text { Narjess Boubakri, Jean-Claude } \\
\text { Cosset, and Omrane Guedhami }\end{array}$ & Dec. 2001 \\
\hline $\begin{array}{l}\text { No. 418: The European Data Privacy Directive and International } \\
\text { Relations }\end{array}$ & Steven R. Salbu & Dec. 2001 \\
\hline $\begin{array}{l}\text { No. 417: Capital Markets and Capital Allocation: Implications for } \\
\text { Economies in Transition }\end{array}$ & $\begin{array}{l}\text { Artyom Durnev, Randall Morck, } \\
\text { and Bernard Yeung }\end{array}$ & Dec. 2001 \\
\hline $\begin{array}{l}\text { No. 416: Forthcoming in: The Journal of Economic Perspectives, "Data } \\
\text { Watch. Research Data from Transition Economies," 16(2) Feb. } 2002 .\end{array}$ & $\begin{array}{l}\text { Randall K. Filer and Jan } \\
\text { Hanousek }\end{array}$ & Dec. 2001 \\
\hline $\begin{array}{l}\text { No. 415: Forthcoming in: The Journal of Economic Perspectives, } \\
\text { "Transition Economies: Performance and Challenges," 16(2) Feb. } 2002 .\end{array}$ & Jan Svejnar & Dec. 2001 \\
\hline $\begin{array}{l}\text { No. } 414 \text { Forthcoming in: The Journal of Economic Perspectives, "The } \\
\text { Great Divide and Beyond: Financial Architecture in Transition," 16(2) } \\
\text { Feb. } 2002 .\end{array}$ & Erik Berglof and Patrick Bolton & Dec. 2001 \\
\hline $\begin{array}{l}\text { No. } 413 \text { Forthcoming in: The Journal of Economic Perspectives, "The } \\
\text { Political Economy of Transition," 16(2) Feb. } 2002 .\end{array}$ & Gérard Roland & Dec. 2001 \\
\hline $\begin{array}{l}\text { No. 412: The Response of Consumption in Russian Households to } \\
\text { Economic Shocks }\end{array}$ & Steven Stillman & Oct. 2001 \\
\hline No. 411: Mark-ups in Hungarian Corporate Sector & László Halpern and Gábor Körösi & Aug. 2001 \\
\hline $\begin{array}{l}\text { No. } 410 \text { Forthcoming in: European Economic Review, "Economic } \\
\text { Development, Legality, and the Transplant Effect." }\end{array}$ & $\begin{array}{l}\text { Daniel Berkowitz, Katarina } \\
\text { Pistor, Jean-Francois Richard }\end{array}$ & Sept. 2001 \\
\hline No. 409: Development Strategy, Viability, and Economic Convergence & Justin Yifu Lin & Oct. 2001 \\
\hline No. 408: Labor Supply, Informal Economy and Russian Transition & Maxim Bouev & May 2001 \\
\hline
\end{tabular}

